\title{
PROFESSOR OF ANIMAL SCIENCE - OTHER
}

\author{
by Martin L. Nelwan \\ The Nelwan's Approach
}

\begin{abstract}
I have found that my professor position is in animal science - other. As a professor of animal science - other, I meet the requirements in order to fill positions such as professor of animal science - other, adjunct professor, Chair of Graduate Studies Committee, Director of Admissions Office, President of Higher Education at other institutions. I have experience for those jobs. I conducted my professor study at Nelwan Institution for Human Resource Development (NIHRD), also called the Nelwan's Approach. The Institution is a formal, a nonformal, an informal institution. It may arrange education activities in either rural or urban area. The Institution is the same as me, Martin L. Nelwan. My education method may give opportunity to talented people to pursue academic degrees and professor positions of animal science - other. They may also pursue positions such as Director of Admissions and Chair of Graduate Studies Committee.
\end{abstract}

Keywords: education, undergraduate, graduate, professor

\section{INTRODUCTION}

Self-directed learning is possible and important. It may be conducted everywhere, in rural or urban area. I have experience regarding how to pursue academic degrees or even a professor position based on this method. In my method, it is possible to conduct self-directed learning for higher education that related to kindergarten to high school levels. To conduct this, it needs, for example, skills at least four fields (biochemistry, genetics, etc.) or an institution as NIHRD. The Institution is needed to develop self-directed learning towards taught education to others. Skills, 
which may be got by self-directed learning, are needed to teach and give examinations to others, for example.

Self-directed learning is not easy. It is competitive against formal higher education institutions. In my case, I studied book after another that related to my education background. Books, which I studied, included such as genetics and statistics. Genetics was related to animal science as animal breeding for both undergraduate level and graduate level. Statistics was also related to animal science and genetics such as experimental design and probability ${ }^{1}$.

Nelwan Institution for Human Resource Development was established in 1984. It was established in Palu, Central Sulawesi, Indonesia. It was established based on Minahasan's culture, custom, or motto. The Institution is the same as me, Martin L. Nelwan, Professor of Animal Science - Other. NIHRD can be stated as a formal, a nonformal, or an informal institution. It is stated as a formal institution since it conducts education activities based on formal needs. It is stated as a nonformal institution since Indonesia Directorate-General of Higher Education registered it as a course institution in 2004. The Institution is stated as an informal institution since it was established based on Minahasan's culture, custom, or motto ${ }^{2}$.

My undergraduate degree, doctorate, or professor study was conducted at NIHRD in animal science - other. This educational background is the same as others from other higher education institutions such as The Ohio State University and Harvard University ${ }^{2}$.

Everyone, who already holds academic degrees based on self-directed learning, should communicate with a higher education institution such as NIHRD, The Ohio State University, and MIT in order to hold formal academic degrees. Before contacting a higher education institution, a holder of higher education degree should have considered that she/he already holds a higher 
education degree. It should also be established a formal, a nonformal or an informal institution as NIHRD to develop education.

My education system may help people in either rural or urban area to pursue a program for higher education purposes. No one in my family holds academic degrees and professor position based on Minahasan's culture, except me, so far. To explain this experience, it had been conducted a research as indicated below.

\section{MATERIALS AND METHODS}

\section{Letters and E-mails}

1. Letters were sent to Ohio State University (OSU) Admissions Office and Chair of Graduate Studies Committee in Agricultural Education.

2. E-mails were sent to OSU Admissions Office, Chair of Graduate Studies Committee in Agricultural Education and in Human and Community Resource Development. Agricultural Education is the same as Human and Community Resource Development.

3. Email was sent to OSU Department of Computer Science.

4. E-mail was sent to University of California, Santa Cruz, (UCSC) Baskin School of Engineering.

5. Letters were sent to Indonesia Department of National Education.

6. Letters and e-mails were sent to me by OSU Admissions Office, Chair of Graduate Studies Committee in Agricultural Education and in Human and Community Resource Development.

7. Emails were sent to me by UCSC Baskin School of Engineering.

8. E-mail was sent to me by OSU Department of Computer Science. 
9. Letters were sent to me by Indonesia Department of Education and Culture, Department of National Education. Department of Education and Culture is the same as Department of National Education.

\section{$\underline{\text { Purposes in Sending Letters and Emails }}$}

Letters and e-mails, which were sent to The Ohio State University, were for pursuing Ph.D. program in Department of Agricultural Education. All of them were sent to both the Admissions Office and Chair of Graduate Studies Committee. The Admissions Office required the following:

1. A completed application form.

2. The nonrefundable application fee, $\$ 40.00$.

3. Official copies of transcripts, English translation.

4. Affidavit of financial support.

5. Official TOEFL scores.

The graduate program required the following:

1. Statement of interest.

2. Three letters of recommendation.

3. "Academic" letters of reference.

The information, which was sent to The Ohio State University, was for meeting requirements for Ph.D. level. Medium was Indonesia Post Office and electronic mail. The information, which was sent to Ohio State University Department of Computer Science, was for employment. Letters and e-mails, which were sent to UCSC Baskin School of Engineering, were for adjunct professor position. Letters, which were sent to Indonesia Department of National 
Education, were related to Tadulako University and verification for Nelwan Institution for Human Resource Development.

$\underline{\text { Analysis }}$

Analysis in this research was conducted in order to get evidences regarding professor of animal science - other. Evidences were connected to B.S. and Ph.D. degrees, and positions such as Director of Admissions Office and Chair of Graduate Studies Committee.

\section{DISCUSSION}

Nelwan and Mewengkang Family Names

Both Nelwan and Mewengkang are family names from Minahasa, North Sulawesi, Indonesia. Each family name in Minahasa has a meaning. For Example, Assah means pioneer (pembuka jalan in Indonesian) and Watuseke means brave (berani in Indonesian). Each Minahasa family should have a family name and its meaning ${ }^{3}$.

My surname (family name) is Nelwan. It comes from my father. My mother surname is Mewengkang. I established Nelwan Institution for Human Resource Development based on their surnames. Nelwan means flying tool (tempat terbang in Indonesian) and Mewengkang means pioneer (pembuka jalan in Indonesian). However, Nelwan, according to time development, could also be stated as professor, teacher, or others at the present time. Nelwan could be used according to someone talent, in my opinion. Mewengkang seems still relevant to this time. For example, I was born in 1957 by my mother. If I was not born by mother, Nelwan Institution for Human Resource Development would not be established by me. It can be stated that my mother is the key or pioneer in establishment of Nelwan Institution for Human Resource Development.

Nelwan as a surname may be used by my younger brothers and sisters according to their background. I have three brothers and two sisters. All of my brothers are not teachers or 
professors. They are businessman, merchant, and basketball trainer, respectively. One of my sisters is a teacher. The other one has a home business job. All of my brothers and sisters may give the next generations in our family according to their talents, respectively. It may be as flying tool, pioneer, teacher, professor, or others.

Nelwan Institution for Human Resource Development

NIHRD does not transgress Indonesia Constitution of 1945 and Laws \#20 of 2003 Re National Education System. The Institution will not transgress international rules either. In addition, the Institution appreciates opinions that have not yet recognized it as a higher education institution $^{2,3}$.

I established Nelwan Institution for Human Resource Development in order to have academic degrees, academic positions, and education development. My first paper, regarding academic background, indicated about academic degrees and academic position. I also indicated in one of my papers that my education method encourages higher education activities in either rural or urban area. This indicates that this system may be used in other countries in order to develop education.

The Institution has one department; that is, Department of Animal Science - Other. Both undergraduate level and graduate level within the Department arranges six fields. These include the following: animal science, Christian religion, computer science, education, genetics, and mathematics and statistics. NIHRD also has a special status, an advanced study or professor study program. In addition, the Institution educational activities could be related to kindergarten to high school levels.

There are four fields in natural sciences, one social science, and one art and humanities at NIHRD so far. In this institution, fields of genetics, cell biology, microbiology, molecular 
biology, or statistics could be sated as one program only. For example, Ph.D. program in genetics requires core courses as genetics, biochemistry, and research methods in biology. Elective courses depend on student needs; physics, etc. Students could determine core courses they would like to take under permission of advisor.

A sample for a graduate program in biology can be provided as follows:

\section{Core Courses}

Genetics 1

Behavior Genetics 2

Mendelian Genetics 3

Bioinformatics 4

Rotations $3 \mathrm{x}$

Elective Courses

Probability 5

Experimental Design 6

Regression 7

\section{Christian Religion 8}

This sample is for students who plan to write a dissertation that related to behavior genetics and Christian religion. Format in this sample is almost the same as format provided by Harvard University ${ }^{4}$, MIT Department of Biology ${ }^{5}$, and The Ohio State University Department of Agricultural Education ${ }^{6}$.

In my case, I, who took these core courses (genetics, biochemistry, and research methods in biology) and statistics, biology, computer science courses for elective, can also be stated as a statistician, biologist, or geneticist. It should also be known that I also took other core courses as 
statistics. In addition, I may also be an expert in medical sciences, chemistry, or physics; however, for this, I need to take a special student or an advanced study program at NIHRD, MIT, or the Center for Advanced Study in the Social and Behavioral Sciences, for example.

The Institution has vision, mission, goal, education philosophy, teaching philosophy, and administrative philosophy. Vision of the Institution is availability of educators who are able to conduct education for kindergarten, elementary, high school, and higher education levels in the field of animal science - other in either rural or urban area that support diversity based on Christian faith.

Mission It is responsibility for preparing and continuing development of educators in the field that fit with its vision. In accomplishing this mission, the Institution: 1) provides undergraduate, graduate, special status, advanced study and professor study programs; 2) conducts researches in the areas of statistical computer science, curriculum development and proposal writing, and "early" Christian; 3) participates in public service activities; and 4) provides funding for talented students and for staff for their future.

Goal It is to achieve educators who hold associate, undergraduate and graduate degrees in the field of animal science - other. It is also to achieve professor position in that field.

Education, Teaching, and Administrative Philosophies These include the following: education and teaching for everyone, and honestly administrative development.

\section{B.S. and Ph.D. Degrees}

In my letter, that was sent to Ohio State University on April 19, 1995, I indicated that I already hold an undergraduate degree, the Sarjana ${ }^{7}$. However, the Tadulako University and Faculty of Agriculture are not about to give the Sarjana documents to me. I have a paper that related to this academic degree titled Doktor, Sarjana Peternakan dan Tenaga Akademik Produk 
Sistem Pendidikan Indonesia (Doctor and Bachelor of Animal Science, and Faculty Position based on Indonesia Education System). This paper also indicated that I already hold a Ph.D. degree in animal science. The problem between the Tadolako University and I were submitted to Indonesia Vice President in 1992.

It should be known that the problem between the Tadulako University and I were related to genetics of behavior and reproduction, a wedding issue. My paper also indicated that I had an academic position in the University of Indonesia ${ }^{1}$. Unfortunately, I was not registered as a staff at the University of Indonesia by the University and Department of National Education. Perhaps the Department did not forward that paper to the University. I honor their decision(s). I am Professor of Animal Science - Other at NIHRD and President of NIHRD at the president time.

The Ohio State University Chair of Graduate Studies Committee in Agricultural Education indicated in a letter of December 27, 1995 that since I was unable to provide evidence for graduate records, they would not be able to admit me to their Ph.D. program. They could only admit me to the M.S. program. In this letter, it was suggested that I provided additional evidence that would help to alleviate the problem they indicated. To respond this letter, I sent a letter to the Graduate Studies Committee to indicate my quality for graduate study. Chair of Graduate Studies Committee, after reviewing that letter, stated that he continued to have serious reservations regarding my admission. It indicates that my B.S. and Ph.D. degrees can be used in order to pursue a Ph.D. program in Agricultural Education ${ }^{7}$.

In my paper titled Doctor and Bachelor of Animal Science and Faculty Position based on Indonesia Education System, I indicated that I learned deeply Introduction to statistics, experimental design, and biology (genetics). I was an assistant in genetics for undergraduate level at Tadulako University Faculty of Agriculture during $1980-1983^{1}$. I thought I had met 
requirements for the undergraduate advisory committee. Since the Tadulako University did not give me opportunity to complete undergraduate degree, it seemed that the University would not give me opportunity to hold higher degrees or even a professor position. To prevent this, I wrote that paper. I met requirements for a Ph.D. degree in animal science. My academic degrees could also be stated as academic degrees in animal science - other. To strengthen the Ph.D. degree, I contacted some higher education institutions in the U.S., The Ohio Stated University included. The University did not reject my undergraduate and graduate works to apply for either $\mathrm{PhD}$ program or employment in 2005.

The communication between The Ohio State University and I took place around ten years. While communicating with the University, I kept continue to strengthen my educational background. For this, I studied animal breeding, Christian religion, computer science, genetics, education, and mathematics and statistics. As a result, the Admissions Office, Department of Agricultural Education, and Department of Computer Science did not reject my educational background to apply for a $\mathrm{PhD}$ program in 2005 .

At The Ohio State University, applicants who cannot submit academic documents must submit "academic" references. In my case, I submitted evidences for graduate study. These evidences were evaluated by the Chair of Graduate Studies Committee. These documents must be submitted to the Admissions Office, too. When communicating with Dr. Napier, he asked me to send to him my academic records. I submitted those records to him. Perhaps students who have done graduate works elsewhere must submit academic records to advisor candidate for his or her needs.

Before communicating with The Ohio State University, I contacted Minister of Education and Culture that related to academic degrees and faculty position. I also contacted Indonesia 
Vice-President. Unfortunately, Indonesia government did not give me a clear response. The Directorate-General of Higher Education only sent to me the communication between the Directorate and Tadulako University. At that time, my paper was still corrected by me. Then, the last paper that titled Doctor and Bachelor of Animal Science, and Faculty Position based on Indonesia Education System was sent to Indonesia Vice-President, Minister of Education and Culture, Directorate-General of Higher Education and Rector of Tadulako University. There was no response.

In order to develop my ideas for education, I established an institution based on Minahasan's culture, custom, or motto. The Institution is Nelwan Institution for Human Resource Development as indicated above. To develop the Institution, it is used methods used by missionaries that introduced Christian religion in Minahasa. They were Riedel, Schwarz, and Hellendron ${ }^{8}$.

\section{$\underline{\text { Professor Position and Jobs }}$}

In order to hold an undergraduate degree, students must have an advisor, co-advisor (if available), and an undergraduate advisory committee. The committee could consist of three members; that is, chair, co-chair (if available), and one or two members (without co-chair). To hold a graduate degree, students must have an advisor, co-advisor (if available) and a graduate advisory committee. The committee could consist of three to five members (with co-chair). This

format is almost the same as provided by Harvard University Genetics Program ${ }^{9}$, MIT Department of Biology $y^{5}$, and The Ohio State University Graduate Program in Agricultural Education $^{6}$. I already hold B.S. and Ph.D. degrees and based on self-directed learning. It could be stated that I was an advisor for my undergraduate program and was an advisor for my Ph.D. program, too. It could be stated that I was chair, co-chair or advisory member(s) for both 
undergraduate and graduate programs. It means that I at least already hold an associate professor and meet requirements for professor position.

When contacting The Ohio State University, I studied all the letters sent to me by both the Admissions Office and the graduate program. All of them were related to application process works. The Admissions Office is responsible for collecting applications and supporting documents. The graduate study committee evaluates applications and makes admission decisions. I completed all of the requirements for both the Admissions Office and Graduate Studies Committee. I know about how to collect applications and supporting documents and about how to evaluate application and make decisions. I also know about how to provide letters of recommendation. It shows, as I am professor of animal science - other, I meet requirements in order to fill positions such as Director of Admissions Office and Chair of Graduate Studies Committee. It also means that I meet requirements in order to fill other positions such as president position at a higher education institution.

I knew that I had capability for position such as Director of Admissions Office and Chair of Graduate Studies Committee. However, it was difficult for me to share my experience with others without an institution. For this, I established an institution, namely, Nelwan Institution for Human Resource Development and based on Nelwan and Mewengkang Education System, Minahasan's culture, custom, or motto. I considered that the Institution was established in 1984. It was the time when I began in conducting research regarding academic degrees and faculty position. The Institution is the same as me, Martin L. Nelwan. The Institution is a formal, a nonformal and an informal institution.

NIHRD is stated as a formal institution since it arranges educational activities based on formal needs. For example, The Ohio State University, as stated above, accepted documents 
from NIHRD as valid documents. The Ohio State University is an accredited university in the U.S. It indicates that it should be no difficulty for other institutions, particularly higher education institutions, in accepting documents from NIHRD as valid documents. Nelwan Institution for Human Resource Development does not transgress Indonesia Constitution of 1945 and Laws \#20 of 2003 Re National Education System ${ }^{2,3}$.

The Institution is stated as a nonformal institution since Directorate-General of Higher Education registered it as course institution in 2004. Education activities are arranged according to structured and gradual. The activities are for kindergarten to higher education levels. NIHRD does not transgress Indonesia Constitution of 1945 and Laws \#20 of 2003 Re National Education System.

NIHRD is stated as an informal institution since it was established based on Minahasan's culture, custom or motto. Minahasan's motto is "Man Lives to Educate Others". Education activities are arranged according to structured and gradual. The activities are for kindergarten to higher education levels. The Institution does not transgress Indonesia Constitution of 1945 and Laws \#20 Re National Education System.

In my method, anybody, who has an animal science - other background as level as a senior high school or higher may pursue a higher education program for B.S., Ph.D., or professor study online, onsite, or traditional. For example, I was a teacher in a senior high school with an incomplete undergraduate level in animal science when beginning to pursue B.S. and Ph.D. degrees at NIHRD. At present, I already hold B.S. and Ph.D. degrees, and professor of animal science - other. I can teach students for graduate programs.

\section{CONCLUSION}


Based on the above information, it can be concluded that my professor position is in the field of animal science - other. I meet requirements in order to fill positions such as adjunct professor and Chair of Graduate Studies Committee at other institutions. My professor study was conducted at NIHRD, an institution that I established based on Minahasan's culture, custom or motto. The institution meets requirements as a formal, a nonformal, or an informal institution. My education method is useful for education development all over the world

\section{ACKNOWLEDGEMENTS}

This work was supported by the Department of Animal Science - Other at the Nelwan Institution for Human Resource Development. The Institution implements and designs the facility use in this work. The Institution also prepares materials for use.

\section{REFERENCES}

1. Nelwan, M. L. 1987. Doktor, Sarjana Peternakan dan Tenaga Akademik Produk Sistem Pendidikan Indonesia. Palu, NIHRD Department of Animal Science - Other, Unpublished.

2. Nelwan, M. L. 2008. Higher Education Development in either Rural or Urban Area using the Internet and its Supporters, Palu, NIHRD Department of Animal Science-Other, Unpublished.

3. Nelwan, M. L. 2008. Graduate Curriculum of Animal Science-Other. Palu, NIHRD Department of Animal Science - Other, Unpublished.

4. Harvard University. 1995. Courses Offered by the Division of Medical Sciences 19941995.

5. Massachusetts Institute of Technology. Graduate Study in Biology at MIT.

6. The Ohio State University. 1993. Doctor of Philosophy Advising Guide, Agricultural Ed. Revised 4.

7. Nelwan, M. L. 1999. “Accepted” for Admission to The Ohio State University in Agricultural Education PhD Program. Dissertation and Professor Study, Palu, NIHRD Department of Animal Science - Other, Unpublished.

8. Graafland, N. 1991. Minahasa: Negeri, Rakyat, dan Budayanya, terj. L. C. Montolalu. 
Jakarta: PT Pustaka Utama Grafii.

9. Harvard University. 1994. BBS Curriculum for Incoming Students. 


\section{APPENDICES}

Appendices are consisted of some letters and e-mails as indicated in Materials and Methods section. 


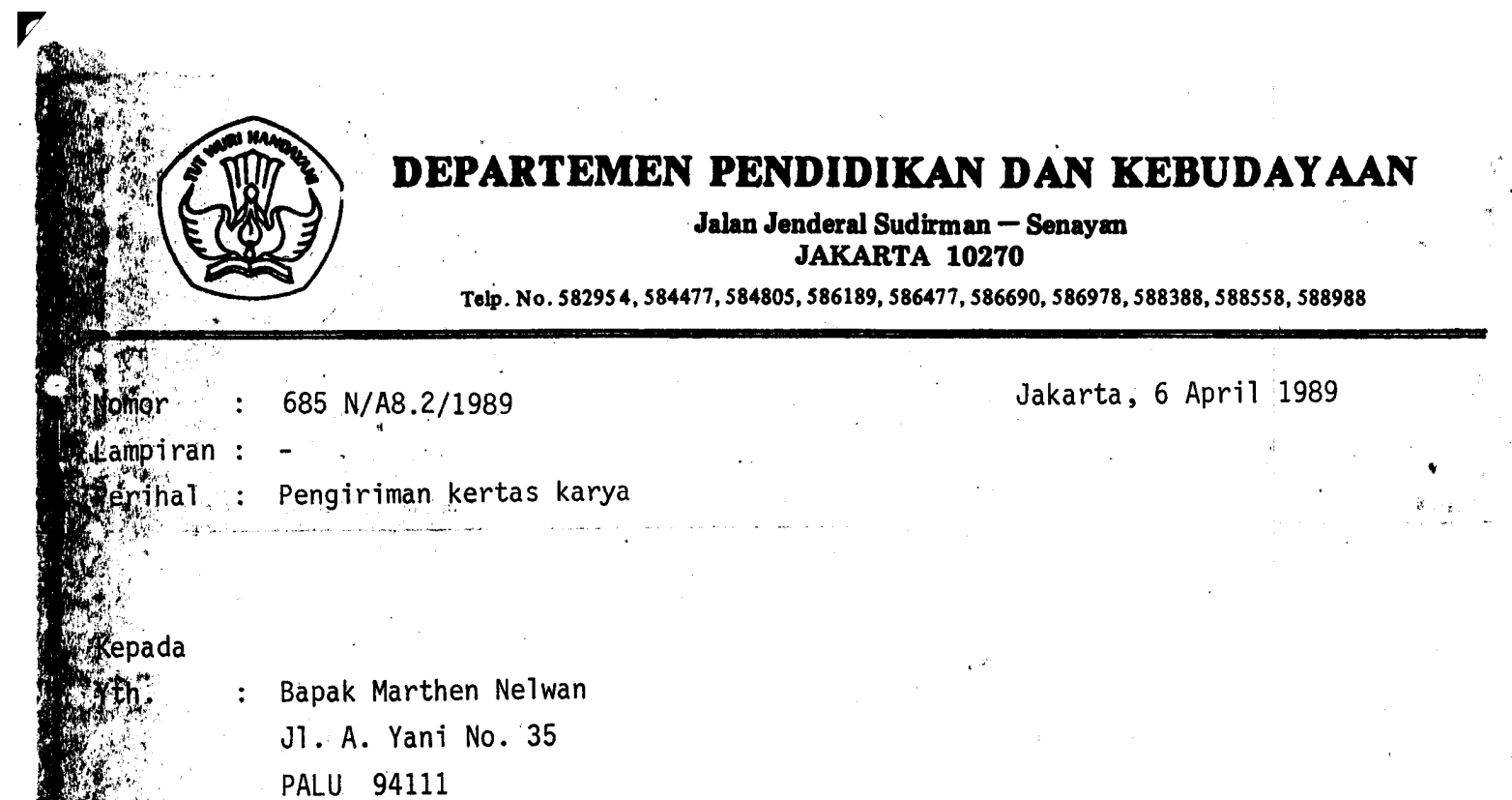

Dengan hormat,

Menangani surat Bapak tanggal Maret 1989 ditujukan kepada Bapak Menteri

Pendidikan dan Kebudayaan-perihal pemberitahuan susulan mengenai pengiriman kertas-kertas karya, dengan ini kami sampaikan bahwa kertas karya dan lainlainnya yang dikirimkan dengan surat tercatat No. 530/11 tertanggal 26 De-. sember 1988 diterima tanggal 14 Januari 1989 dan telah diteruskan kepada Direktorat Jenderal Pendidikan Tinggi Departemen Pendidikan dan Kebudayaan untuk mendapat tanggapan seperlunya.

Demikianlah kami sampaikañ untuk dimaklumi.

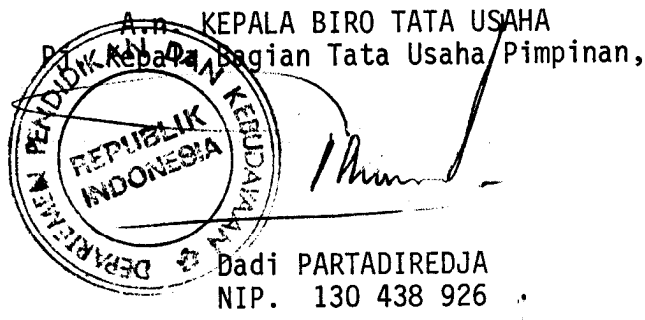




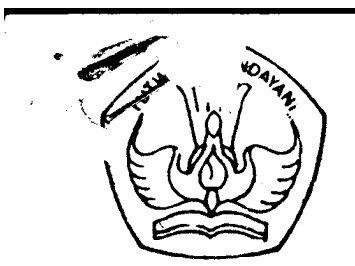

\section{DEPARTEMEN PENDIDIKAN DAN KEGUDAYAAN \\ DIREKTORAT JENDERAL PENDIDIKAN TINGGI}

Jln. Raya Jenderal Soedirman Pintu 1. Senayan, Tromolpos 190. Jakarta 10002

Telp. 581436, 581982, 581466, 581903, 581843, 581805, 581988, 581846, 582481; 582468.

Nomor : $780 / \mathrm{D}$

Lampiran :

Perinal

Kepada Yth.

Sdr. Narthen Nelwan

J1. A. Yani No. 35

$\mathrm{di}$

Palu 94111

Sehubungan dengan surat Saudara tanggal 3 Januari 1990 yang ditujukan kepada Kepala Biro Tata Usaha Departemen Pendidikan dan Kebudayaan tentang permohn.lan tanggapan atas kertas kerja Saudara, dengan ini kami sampaikan tanggapan ciari Pembantu Rektor I Universitas Tadulako mengenai kertas kerja Saudara dengan surat No. 008/PT41.Hl/Q/ 90 tanggal 20 Ianuari 1990, untuk Saudara ketahui.

Atas perhatian Saudara, kami ucapkan terima kasih.

Tembusan : Yth.

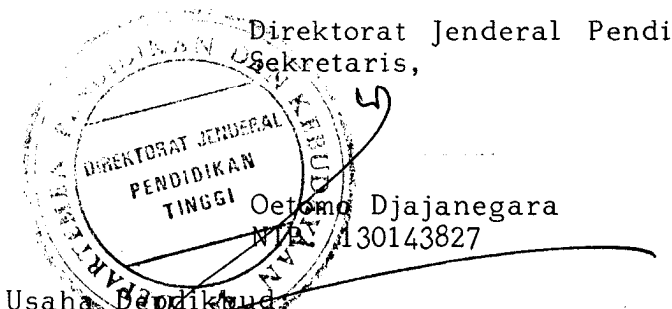

1. Kepala Biro Tat Usaha- Bapriket

2. Pembantu Rektor I UNTADFmis 

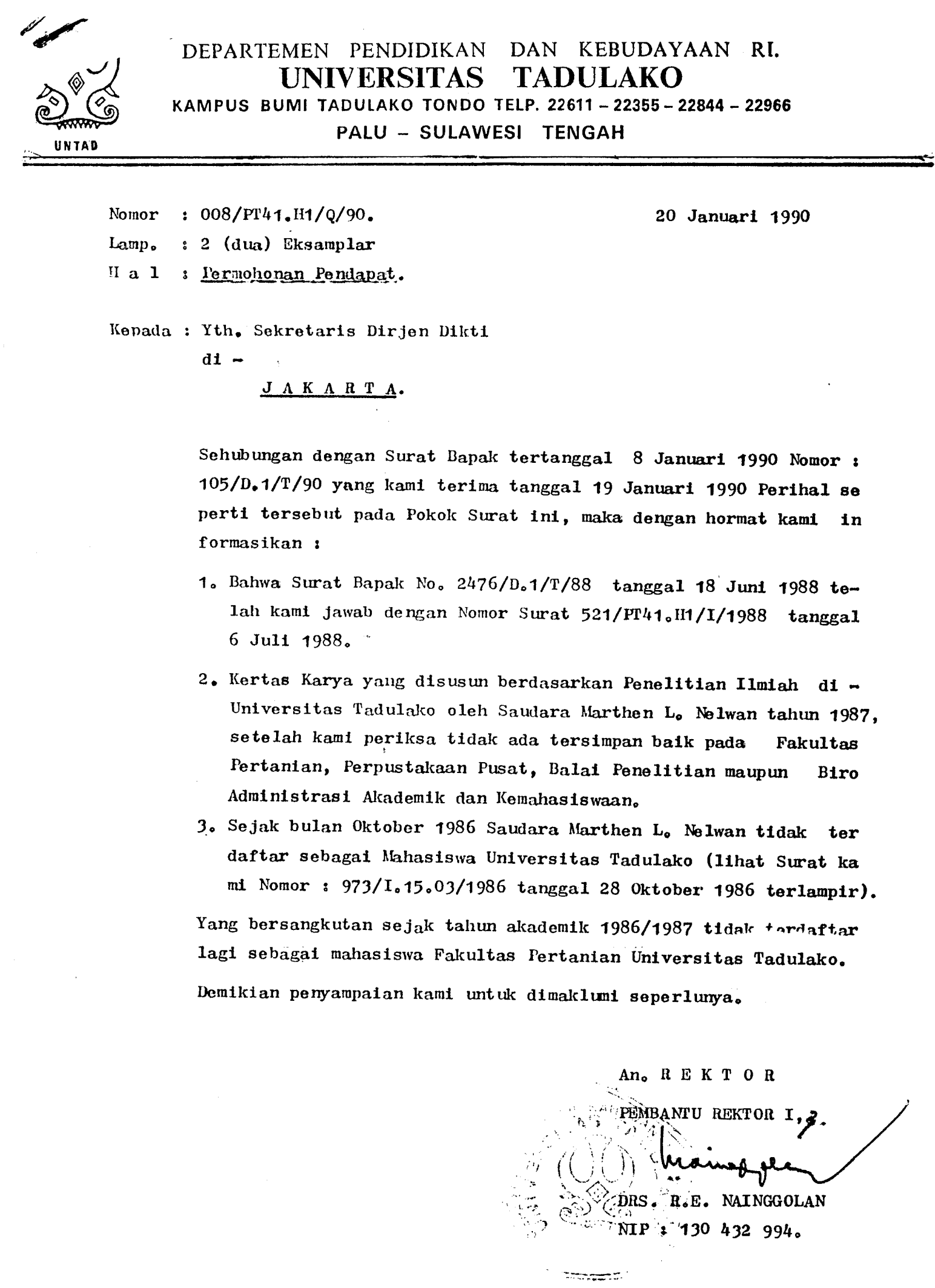
DEPARTEMEN PENDIDIKAN DAN KEBUDAYAAN R.I.

UNIVEIRSITAS TADULAKO

(2) UNTAD

KAMPUS BUMI TADULAKO TONDO TELP. 22611-22355-22844

PALU SULAWESI - TENGAH

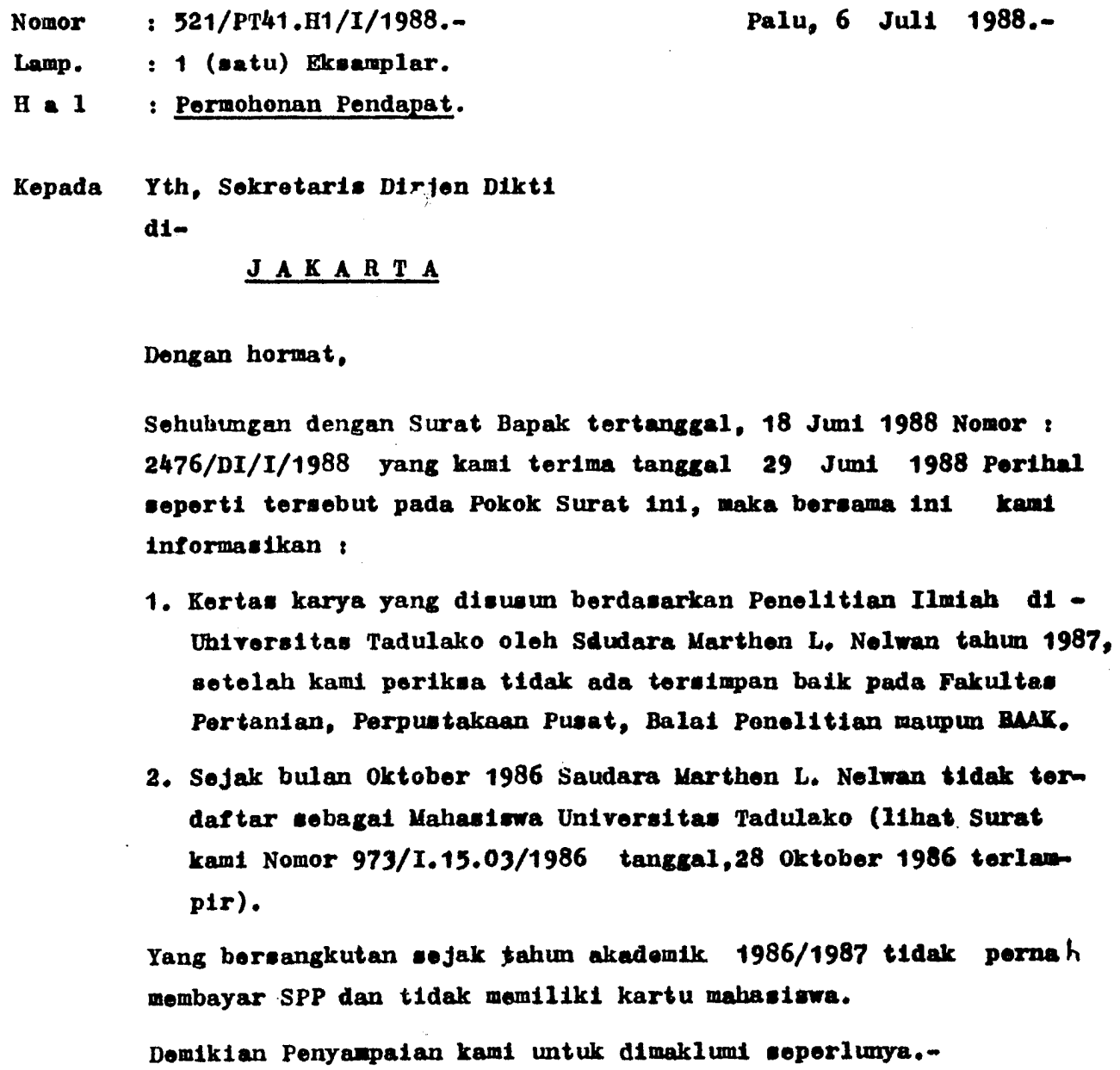

1. Kortas karya yang disusun berdasarkan Penolitian I1miah d1 Uhiversitas Tadulako oloh Sdudara Marthon L. Nelwan tahum 1987, sotelah kami porikaa tidak ada toruimpan baik pada Fakulta. Portanian, Perpustakaan Pueat, Balal Ponelitian maupun BuK.

2. Sojak bulan Oktober 1986 Saudara Marthon L. Nelwan t1dak torm daftar cobagal Mahasiswa Universitas Tadulako (11hat. Surat kami Nomor 973/1.15.03/1986 tangeal,28 Oktober 1986 torlanpir).

Yang bersangkutan sejak tahun akademlk 1986/1987 t1dak pernah membayar SPP dan t1dak momilik1 kartu mahasiewa.

Demikian Penyanpaian kami untuk dimaklumi soperlunya.-

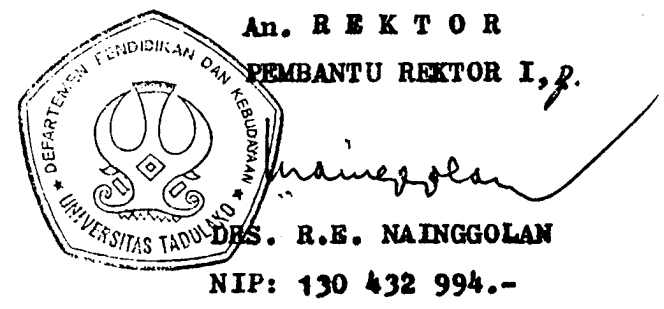



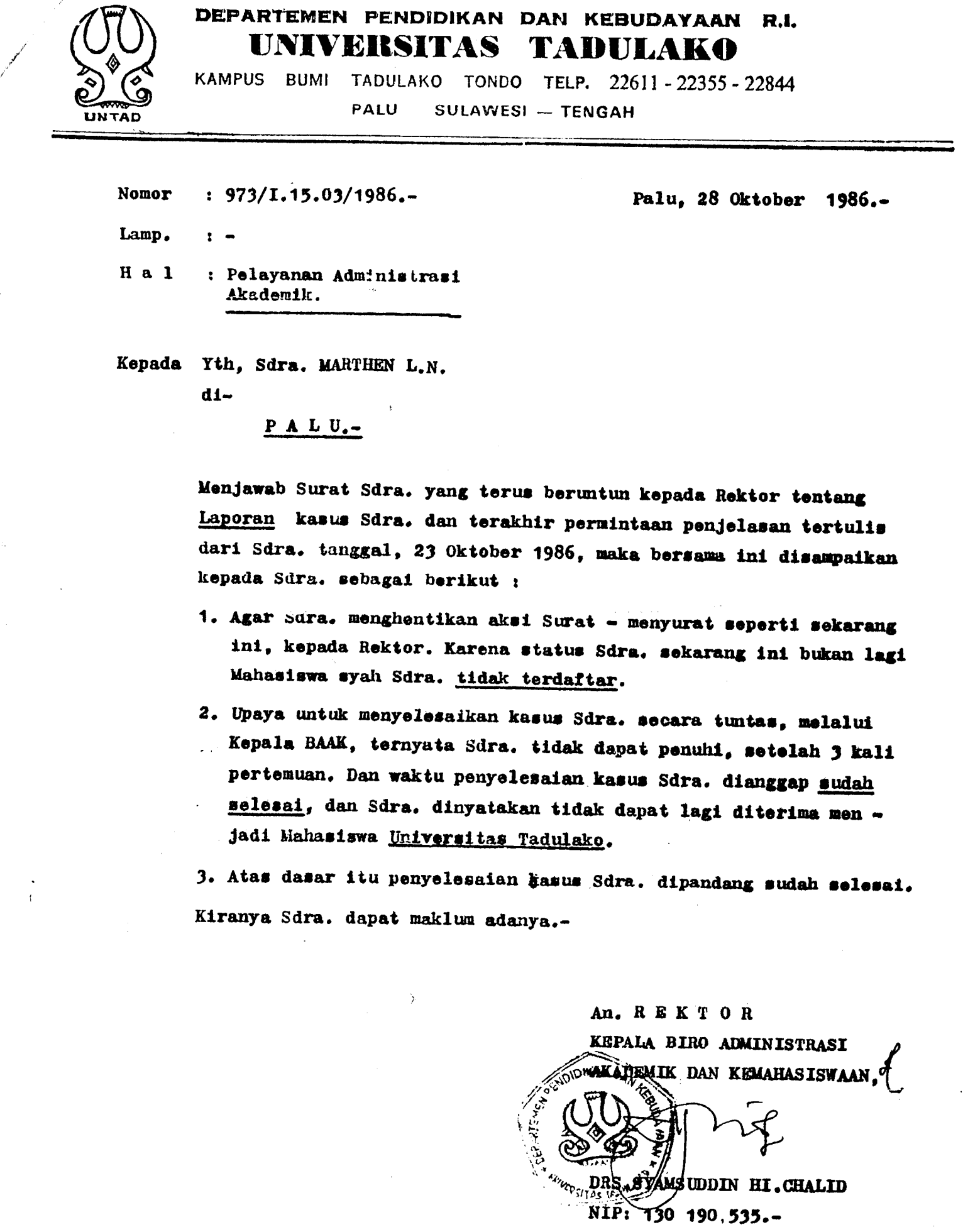


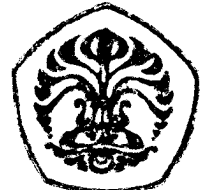

\title{
DEPARTEMEN PENDIDIKan DAN KeBudayaAN \\ UNIVERGITAB INDONEGIA \\ BALEMBA 4 - JAKARTA 10430
}

TELP. 330355-330328,330337, 330343, 330353, 330356, 330393, 341345-TELEX 69158 UI. JKT. IA. KAWAT : UNIV KAMPUS BARU TELP. 7270016, 7270018, 7270020, 7270021, 7270022, 7270023, 7270024, 7270025, FAX-(021) 7270017 DEPOK.

\author{
Nomor : 2/9/PT02.H14.3/U/1994 \\ Lampiran: \\ Hal : Melanjutkan pendidikan di \\ Perguruan Tinggi
}

Kepada : Yth. Sdr. Marthen Nelwan

Jalan A. Yani No. 33

Palu 94111

\begin{abstract}
Merujuk kepada surat Saudara yang bermaksud hendak melanjutkan pendidikan di Universitas Indonesia, khususnya keterampilan laboratorium dalam bidang biologi, maka dapat saya jabarkan persyaratan umum untuk melanjutkan studi sebagai berikut:
\end{abstract}

1. Persyaratan administrasi: artinya untuk melanjutkan pendidikan ke jenjang yang lebih tinggi harus mempunyai bukti telah menyelesaikan pendidikan setingkat dibawahnya.

Mengambil D3 atau S1 harus mempunyai Ijazah/STTB SLTA Umum/Kejuruan,

Mengambil S2 harus mempunyai ijazah $\mathrm{S} 1$.

2. Persyaratan akademik: harus lulus seleksi. Seleksi dapat merupakan ujian tulis atau bentuk lain sesuai dengan peraturan yang berlaku di Perguruan Tinggi.

3. Biaya: Perguruan Tinggi tidak memberikan beasiswa. Beasiswa diberikan oleh lembaga di luar perguruan tinggi.

Mengingat bahwa Saudara lulusan program studi peternakan Universitas Tadulako, dan minat Saudara adalah meningkatkan keterampilan (pengetahuan) dalam bidang Biologi, maka tersimpulkan bahwa Saudara bermaksud hendak melakukan penelitian untuk jenjang yang lebih tinggi, maka kiranya Saudara harus terlebih dahulu memenuhi persyaratan di atas terutama butir 1 dan 2 .

Terima kasih.

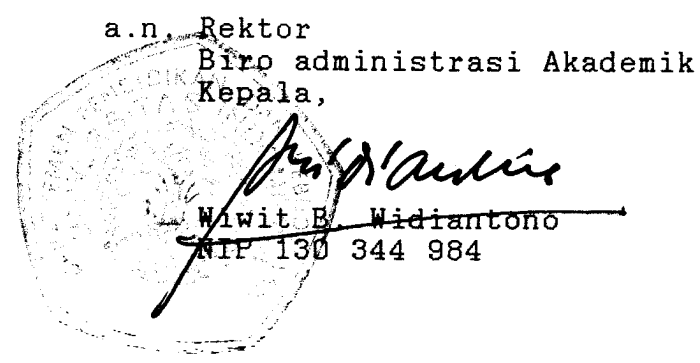




\title{
The Ohio State University
}

Www.osu.edu

\author{
lleip
}

(ampus maia

Find people

Search Ohio State

Admissioni Application Status

\section{Admission Application Status}

$\begin{array}{ll}\text { Name: } & \text { MR. MARTIN LUTHER NELWAN } \\ \text { Date of Birth: } & \text { OCTOBER 31, 1957 } \\ \text { Address: } & \text { J1 A YAMI \#24 } \\ & \text { PALU,94111 INDONESIA } \\ \text { Email Address: } & \text { MARTINNELWAN333@HOTMAIL.COM }\end{array}$

Applications on file:

\begin{tabular}{|c|c|c|c|c|}
\hline$\underline{\text { Term }}$ & $\underline{\text { Level }}$ & $\underline{\text { Major }}$ & Campus & $\underline{\text { Status }}$ \\
\hline 1. AUTUMN 05 & GRAD & HCRD & COLUMBUS & DECISION \\
\hline
\end{tabular}

Status by Application:

Term: AUTUMN 05

Level: GRADUATE.

Major: HUMAN AND COMMUNITY RESOURCE DEVELOPMENT.

College: GRADUATE SCHOOL.

Campus: COlUMBUS. 


\section{nongenail}

martinnelwarl333@hotmail,com

Printed: Tuesday, May 9, 2006 12:02 PM

From : $\quad$ Facully Search <fsearch@cse.ohio-state.edu>

Sent: $\quad$ Wednesday, August 24, 2005 10:35 PM

To: $\quad$ "Martin Nelwan"<martinnelwan333@hotmail.com>

Subject: Re: Faculty Recruiting

Dear Dr. Neiwan,

Thank you for your interest in the Department of Computer Science \& Engineering of The Ohio State University.

However, at this time we are not reviewing any applications. We anticipate that our 2005/2006 facklty recruitment activities will begin in late Autumn or early Winter. As it is summer our faculty search committee as not yet met and defined our needs for the coming year. We will advertise with the najor outlets as well as on our website. If you still wish to be considered, please re-submit the appropriate application materials then.

Mnasen

Tamera Cramer

Learning is rot attained by chance, it must be sought for wi.th ardor and attended to with diligence.

E.bagail Adams in a Letter to John Quincy Adams, May 1780

(614) 292-6875 Fax: (514) 292-2911

Eaculty Search Secretary / Computer Science \& Enqineering

The Ohio Sta:a University

395-F Dreese Labs 2015 Neil Ave.

Columbus, 44210 


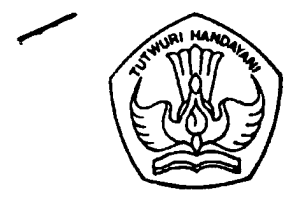

\section{DEPARTEMEN PENDIDIKAN NASIONAL}

DIREKTORAT JENDERAL PENDIDIKAN TINGGI

Jin. Raya Jenderal Soedirman Pintu I, Senayan Tromolpos 190, Jakarta 10002

Telp. : (021) 5731436, 5731988, 5731152, 5731903

Fax. (021) 5731466, 5731988, 5731903. Email: dikti@dikti.org

Nomor

: $1844 / \mathrm{D} 5 \cdot 3 / \mathrm{T} / 2004$

Jakarta, 30 Juni 2004

Lampiran

:- -

Perihal : Mohon Verifikasi masalah

Kepada Yth. : Sdr. Martin L. Nelwan

J. A. Yani No.24. P a 1 u

Merujuk surat Saudara perihal Permohonan Verifikasi Institusi Nelwan untuk pengembangan Sumber Daya Manusia atau Nelwan Institution for Human Resource Development (NIHRD) tanggal 14 Juni 2004, dengan hormat kami sampaikan hal - hal sebagai berikut :

1. Mohon penjelasan lebih lanjut mengenai maksud surat Saudara tersebut agar kami dapat menindaklanjutinya dengan baik dan tepat.

2. Lembaga Nelwan Institution for Human Resource Development (NIHRD) hingga saat ini tidak terdaftar sebagai lembaga pendidikan tinggi pada Direktorat Jenderal Pendidikan Tinggi, namun tercatat sebagai lembaga kursus pada Direktorat Jenderai Pendidikan Luar Sekolah dan Olah Raga.

Demikian kami sampaikan, atas perhatian Saudara diucapkan terimakasih.

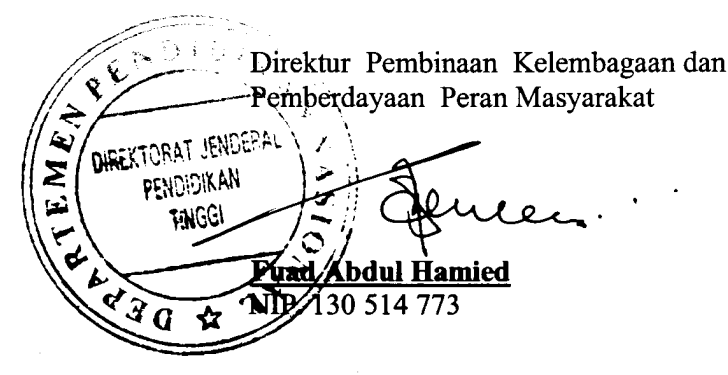

Tembusan Yth.:

1. Ditjen Pendidikan Tinggi

2. Sesjen Depdiknas

3. Ditjen Diklusepa

Klrifikasi/dist Monev FKK 


\title{
DEPARTEMEN PENDIDIKAN NASIONAL DIREKTORAT JENDERAL PENDIDIKAN TINGGI
}

Jl. Raya Jenderal Sudirman, Pintu I, Senayan, Tromol Pos 190 Jakarta 10002 Telp. 5731956 (Hunting)

$\begin{array}{lll}\text { Nomor } & : 3076 / \mathrm{D} 5.1 / \mathrm{T} / 2004 & 27 \text { SEP } 2004 \\ \text { Lampiran } & : & \\ \text { Perihal } & : \text { Verifikasi masalah. }\end{array}$

\author{
Kepada Yth : Sdr. Martin L. Nelwan \\ Jl. A. Yani No. 24 \\ Palu.
}

Menanggapi surat Saudara tanggal 24 Juli 2004 perihal seperti tersebut pada pokok surat, serta melengkapi surat kami no. 1844/D5.3/T/2004 tanggal 30 Juni 2004, dengan ini diberitahukan bahwa pengakuan NIHRD sebagai institusi Pendidikan Tinggi oleh Departemen Pendidikan Nasional harus melalui tahapan sebagai berikut :

1. Pendirian suatu Perguruan Tinggi melalui proses tata cara dan persyaratan yang harus dipenuhi oleh pemrakarsa.

2. Usul pendirian Perguruan Tinggi harus mengacu pada Keputusan Mendiknas No. 234/U/2000 tentang Pedoman Pendirian Perguruan Tinggi dan Keputusan Dirjen Pendidikan Tinggi No. 108/Dikti/kep/2000 tentang Pedoman Pelaksanaannya.

3. Usul Pendirian Perguruan Tinggi disampaikan kepada Dirjen Pendidikan Tinggi dilengkapi dengan persyaratan Pendirian Perguruan Tinggi dan hasil studi kelayakan sesuai dengan pasal 4 \& 6 Kepmendiknas No. 234/U/2000.

Kami informasikan bahwa pada saat ini Ditjen Pendidikan Tinggi sedang melakukan penataan kembali terhadap keberadaan Perguruan Tinggi Negeri maupun Swasta, dengan demikian permohonan pendirian Perguruan Tinggi baru belum dapat dipertimbangkan sampai dengan selesainya seluruh proses penataan.

Atas perhatian Saudara, kami ucapkan terima kasih.

Tembusan :

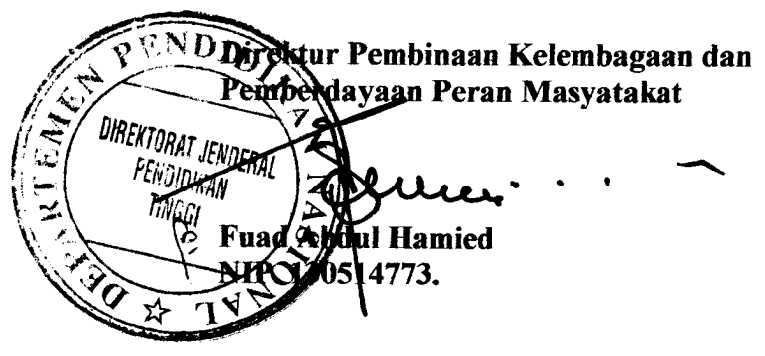

Dirjen Pendidikan Tinggi ( sebagai laporan) 


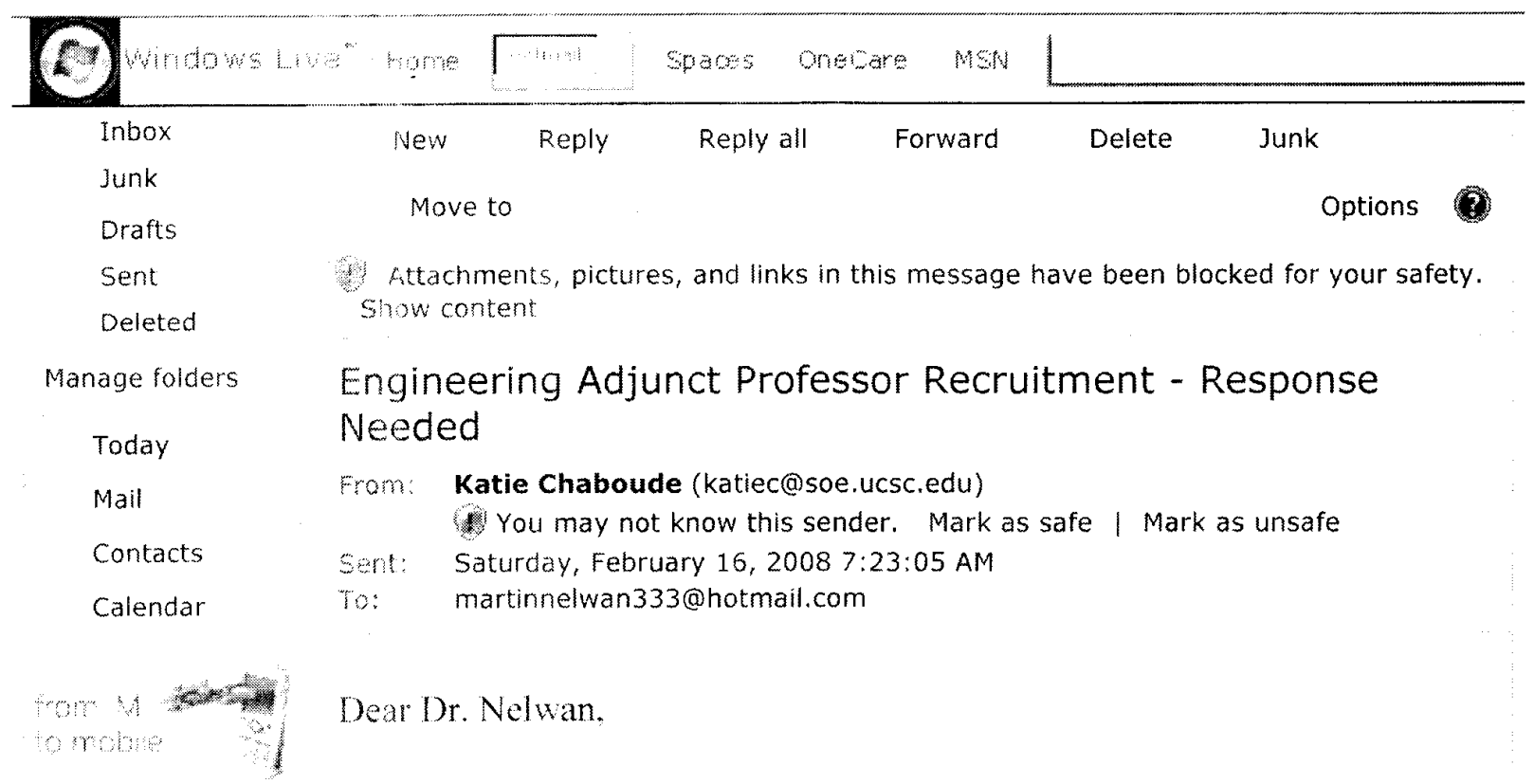

Thank you for applying to the UC Santa Cruz Baskin School of Engineering Adjunct Pool T06-06.

This is to notify you that we are closing this recruitment pool and will be replacing it with ongoing recruitments which are department/program specific. Please review the job descriptions for the new department/program pools using the links below. In order to remain a candidate for any adjunct position. please reply to adjunct@soe.ucsc.edu and state the adjunct position code and department of interest and provide an updated CV by MARCH 31, 2008. By confirming your interest at this time, your application will remain on file with the new pool(s) for three years. If we do not hear from you by March 31,2008, we will remove your name from the pool; however, you may re-apply at any time.

Please send additional questions to adjunct@soe.ucsc.edu.

Applied Mathematics and Statistics Pool \# T08-18:

http://www.soe.ucsc.edu/jobs/faculty/adjunct/T08-18.pdf

l:-mail: adjunct@soe.ucsc.edu 


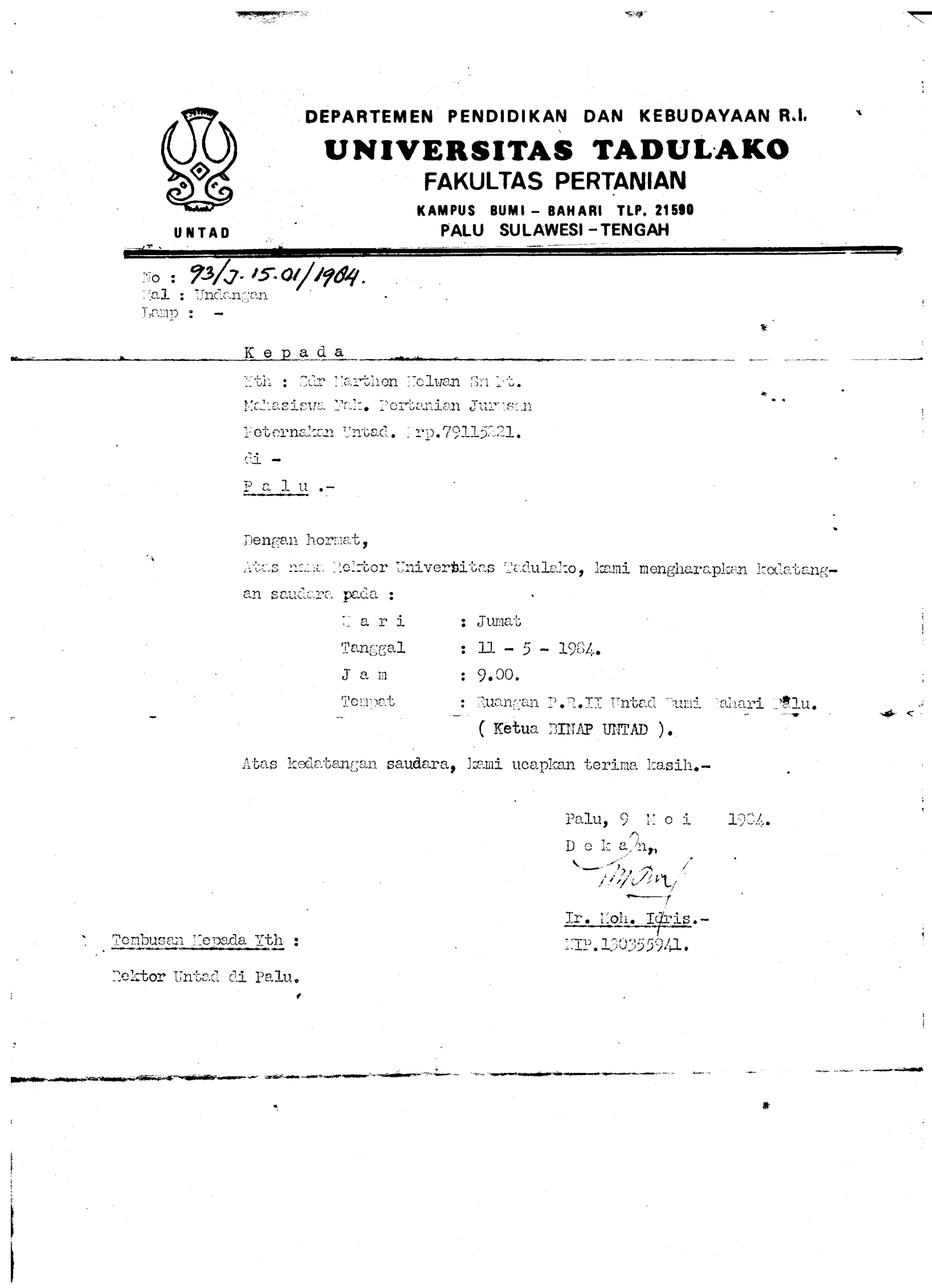

